International Journal of Social Science and Economic Research

ISSN: 2455-8834

Volume: 05, Issue: 06 "June 2020"

\title{
AT THE ORIGINS OF METHODISM: SUSANNA WESLEY
}

\author{
Ada Prisco \\ Istituto Superiore di Scienze Religiose Metropolitano (ISSRM) di Foggia - Italy \\ DOI: 10.46609/IJSSER.2020.v05i06.003 URL: https://doi.org/10.46609/IJSSER.2020.v05i06.003
}

\begin{abstract}
The article focuses on the origins of Methodism. In particular, it examines the figure of Susanna Wesley, mother of John Wesley. The woman, framed in the historical age and in the light of her personal events, appears of great importance for her independent thought, for the support and inspiration that she could give, with words and works, in the foundation of the movement and in decisive advance with regard to women's education and gender equality. An "ante litteram" pastor?
\end{abstract}

Keywords: origins, Methodism, gender issues, pastoral ministry, religious experience.

\section{INTRODUCTION}

Susanna Wesley (1669-1742) is best remembered for being the mother of John and Charles Wesley, founding fathers of Methodism. Her figure thus risks being unfairly neglected. In stark contrast to the times, she had been a rebellious, educated young woman with an autonomous thought, and a bearer of a spirituality, which certainly influenced her children and their religious conceptions. It is no coincidence that she has been called the Mother of Methodism ${ }^{l}$, she is named a foundation ${ }^{2}$ and some interesting contributions circulate on her account. In particular, she herself has authored many of the poems of a religious nature ${ }^{3}$. Some biographical circumstances make it special, as she was born the daughter of the Puritan pastor Samuel Annesley (1620-1696), who had left the state Anglican Church for the benefit of Presbyterianism. However, at the age of thirteen she decided not to follow her father's

1 Day, Alfred T. 2016. Susanna Wesley: mother of Methodism. Accessed October 12, 2019. http://www.umc.org/who-we-are/susanna-wesley-mother-of-methodism.

${ }^{2}$ The Susanna Wesley Foundation based in Roehampton, London, UK. Accessed October 12, 2019. http://susannawesleyfoundation.org.

${ }^{3}$ Many of these were collected in the edition edited by Wallace, Charles. 1997. Susanna Wesley: the complete writings. Oxford: Oxford University Press. 


\section{International Journal of Social Science and Economic Research}

ISSN: $2455-8834$

Volume: 05, Issue: 06 "June 2020"

controversy and to return to the Church of England. In 1688, when she was nineteen, she married the Anglican priest and poet, Samuel Wesley (1662-1735), whom she had met when he attended her home as a seminarian. And, as it is well known, she became a mother of nineteen children, nine of whom died at an early age. Among the three surviving males, the two cited were promoters of the Protestant current of Methodism.

Susanna's family life was never relegated to the care of the home, but rather as a special and finalized care of people: her husband, her husband's work, her children, her community of faith. As for her husband, despite being a poet, he never gained popularity either as a literary man or as a minister of worship. When he left for work, Susanna continued his pastoral commitment, gathering the community at home for biblical reading and reflection. She had undertaken this activity as a Sunday school for her children, but she had ended up attracting many of her neighbors ${ }^{4}$ :

Last Sunday I believe we had above two hundred. And yet many went away, for want of room to stand.

Her son John kept within him the tender memory of his mother's ordained gatherings on Sunday afternoons, in his life as a preacher from time to time re-emerged to his conscience.

Susanna taught herself to read and write to her children, providing a detailed schedule, with morning and afternoon hours for a total of six hours a day. Prayer was never lacking. In addition, she had developed a calendar and dedicated a specific time to each child, based on the belief expressed in the sixteen points of her educational program, that each of them should learn to pray as soon as he or she could speak.

In addition to the peculiarity of her biography, the importance of some events is not negligible. Already a free thinking professor as a teenager, Susanna continued to freely express her opinion about religious matters with her husband. In 1709 a dramatic episode occurred that increased her confidence in the divine Providence. Their home, Epworth Rectory, was set on fire and completely destroyed, but her children miraculously managed to get out of it unscathed.

\section{SPIRITUAL ROOTS}

Puritanism ${ }^{5}$ was a fundamental trace for the spirituality of the Mother of Methodism. It guided her in considering life in the spirit as a daily commitment, to be neatly and regularly on the

\footnotetext{
${ }^{4}$ Tucker, Ruth A. 1988. First Ladies of the Parish: Historical Portraits of Pastors' Wives. Grand Rapids, MI: Ministry Resources Library, Zondervan Publishing House, 56.

${ }^{5}$ Newton, John A. 1968. Susanna Wesley and the Puritan Tradition in Methodism. London: Epworth, 32-33, 36, 40, 135 .
} 


\section{International Journal of Social Science and Economic Research}

ISSN: $2455-8834$

Volume: 05, Issue: 06 "June 2020"

agenda for herself and her loved ones. The simple and tenacious trust, at the same time in God and in the gifts he gives, allowed her to express her voice in opposition to a masculine and patriarchal system. Women were permitted to think, but not to speak.

Susanna's day was affected by the puritan influence; it was set on a spiritual pattern. The great matrix of Puritanism was Calvinism, declined with the aim of purifying 16th-century English religiosity, focusing more on the Bible, less on contamination from the Anglican Communion by Catholicism. Spiritual perfection was pursued by looking at Christ as the only true point of reference. Loyalty to him had to be expressed through a coherent moral life. Prayer, the examination of conscience, the meditation of the scriptures, and regular participation in liturgical services were pivotal to the daily life of Susanna. She nurtured great faith in the real presence of the Lord Jesus in the sacred species and sought to prepare in the best way to receive him sacramentally. Sunday had the true importance as the day of the Lord, a great opportunity to experience life on a higher level. Prayer, meditation, biblical reading were not lacking in her or her specific teaching for each of her children.

Compared to the Moravian Church $^{6}$ and the Quietists ${ }^{7}$ she never devalued the authority of the belief structured in practice, which, in some way, helped to realize in the warmth of her family and at the service of her community of faith.

Anglican spirituality represents the hive in which Susanna chose to remain, so it cannot be ignored in her profile, as well as Puritanism that belonged to her for cultural climate, family history. Moreover, she was certainly a forerunner of the new spirituality that was emerging in to Anglicanism ${ }^{8}$.

Although rebellious to her father's authority and even to his religious choices, she had absorbed from the Pastor Annesley the emphasis on conscience, a focal point of reform in general. Susanna calls for the right to the freedom of conscience, in advance of the Enlightenment, civil battles and gender claims. She affirms that clearly, when her husband distances himself from her that she refuses to join the prayer in favor of King William III of Orange (1650-1702), for she considered him a usurper ${ }^{9}$, preferring him James II Stuart (1633-1701). Her husband reacted, walking away, with these words ${ }^{10}$ :

\footnotetext{
${ }^{6}$ They are also called Unitas fratrum, Unity of the Brethren. They are a Christian religious group born from the Hussite movement, in Bohemia, in the second half of the fifteenth century.

${ }^{7}$ Quietism is a mystical doctrine that spread in the seventeenth century following the preaching of the theologian Miguel de Molinos and tends towards Christian perfection through closeness to God.

${ }^{8}$ Wallace, Charles jr. 1984. "Susanna Wesley's spirituality: the freedom of a Christian woman". Methodist history, 22(3):158ss.

${ }^{9}$ Metaxas,Eric. 2015. Seven Women and the Secret of their Greatness. Nashville Tennessee: Nelson Books, 37.
} 


\section{International Journal of Social Science and Economic Research}

ISSN: $2455-8834$

Volume: 05, Issue: 06 "June 2020"

We must part for if we have two kings, we must have two beds.

Not only the woman did not break down, but on 7 March 1701 she wrote ${ }^{11}$ to her friend, Lady Yarborough, born Henrietta Maria Blagge:

... since I'm willing to let him quietly enjoy his opinions, he ought not to deprive me of my little liberty of conscience.

They reconciled when her husband returned home after the fire. Otherwise John, the official father of Methodism, would never have been conceived.

Wesley had breathed in the unconventional ${ }^{12}$ climate that animated the British Protestantism of the time populated by particular Baptists, Presbyterians, Quakers, Unitarians, academies of dissent, dwellings that became places of effervescent churches, ready to debate the finest Calvinist theories of salvation, the ideals of perfection, the ways of devotion and church organization. These currents that arose in the broad hive of reform benefited incipient inspirations on gender equality, reinforced by the underlying spiritual freedom of Susanna's family. The only preceptor of her daughters, she refused to let them work at home and teach them how to do it, until they were able to read well ${ }^{13}$. Theological inspirations had to be accompanied by speculative suggestions of a rationalistic and innovative character, such as the reflections of John Locke, Richard Lukas, George Herbert, Richard Baxter, Blaise Pascal. From the Wesley's Diary ${ }^{14}$ it is evident that she cultivated familiarity even with the ancient Greek philosophers ${ }^{15}$. She supported the universality of salvation and encouraged theological speculation of children in this direction, supporting the Arminian soteriology with respect to the strict interpretation of Calvinist predestination. Susanna wrote ${ }^{16}$ in a letter to her son John:

"I have often wondered that men should be so vain as to amuse themselves by searching into the decrees of God which no human wit can fathom and do not rather employ their

\footnotetext{
${ }^{10}$ Tucker, 53.

11 Wesley, 35.

12 Stepney. 1998. "Protestant Nonconformity to 1689". In A History of the County of Middlesex, edited by Thomas Baker, Vol. 11: 81-83. London: Victoria County History. British History Online. Accessed October 5, 2019. http://www.british-history.ac.uk/vch/middx/vol11/pp81-83.

${ }^{13}$ Wesley, John. 1829. The Works of the Rev. John Wesley, A.M.. edited by Thomas Jackson, John Mason. London: Longmans. Vol. I: 393.

${ }^{14}$ Wesley, S. 1709. Devotional Journal. Bristol: Headingley MSS, Wesley College. Westburyon-Trym. Susanna Wesley: the Complete Writings, edited by Charles Wallace Jr. 1997. New York: Oxford University Press.

15 Wallace. 1989. "Some Stated Employment of Your Mind : Reading, Writing, and Religion in the Life of Susanna Wesley". In Church History 58(3), 354-366.

${ }^{16}$ In Kirk, John. 1864. The Mother of the Wesleys: a biography. London: Henry James Tresidder, 284-86.
} 


\section{International Journal of Social Science and Economic Research}

ISSN: $2455-8834$

Volume: 05, Issue: 06 "June 2020"

time and powers in working out their salvation and making their own calling and election sure. Such studies tend more to confound than inform the understanding and young people had best let them alone. But since I find you have some scruples concerning our article of predestination I will tell you my thoughts of the matter and if they satisfy not you may desire your father's direction who is surely better qualified for a casuist than me. The doctrine of predestination as maintained by rigid Calvinists is very shocking and ought utterly to be abhorred because it charges the most holy God with being the author of sin. And I think you reason very well and justly against it for it is certainly inconsistent with the justice and goodness of God to lay any man under either a physical or moral necessity of committing sin and then punish him for doing it. Far be this from the Lord! Shall not the Judge of all the earth do right? I do firmly believe that God from all eternity hath elected some to everlasting life but then I humbly conceive that this election is founded in His foreknowledge according to that in the eighth of Romans. Whom He did foreknow He also did predestinate to be conformed to the image of His Son moreover whom $\mathrm{He}$ did predestinate them $\mathrm{He}$ also called and whom $\mathrm{He}$ called them $\mathrm{He}$ also justified and whom He justified them He also glorified. This is the sum of what I believe concerning predestination which I think is agreeable to the analogy of faith since it does in no wise derogate from the glory of God's free grace nor impair the liberty of man. Nor can it with more reason be supposed that the prescience of God is the cause that so many finally perish than that our knowing the sun will rise to morrow is the cause of its rising. And once more she writes I cannot recollect the passages you mention but believing you do the author I positively aver that he is extremely in the wrong in that impious not to say blasphemous assertion that God by an irresistible decree hath determined any man to be miserable even in this life. His intentions as Himself are holy and just and good and all the miseries incident to men here or hereafter spring from themselves."

Any inspiration had to come true in the religious experience, first of all that of motherhood that Wesley welcomed day after day as a mission field to address to her seven daughters and three boys. Writing to her son John she herself spells out this purpose ${ }^{17}$ :

... hope to save the souls of ... children ... that was my principal intention, however unskillfully or unsuccessfully managed.

\section{RELIGIOUS EXPERIENCE}

Some traits of Susanna's spirituality have left a mark on the nascent 17th-century Methodist movement. First, she was clearly very adept at intercepting the necessities of the moment. The

${ }^{17}$ Wallace, 367. 


\section{International Journal of Social Science and Economic Research}

ISSN: $2455-8834$

Volume: 05, Issue: 06 "June 2020"

phenomenal reading of reality led her to boldly change established traditions and to respond dialectically to her husband who took her back because of the initiative to receive people at home for Bible reading. It was the years between 1711 and 1712, Samuel was out of town, John was still a kid. At her husband's call so Susanna answered ${ }^{18}$ :

If you do, after all, think fit to dissolve this assembly, ... send me your positive command, in such full and express terms as may absolve me from all guilt and punishment for neglecting this opportunity of doing good, who you and I shall appear before the great and awful tribunal of our Lord Jesus Christ.

In addition to the reading of the situation considered with serious discernment on the part of the woman, a preferential perspective is required, according to which the needs of the community precede and include those ones of the individual believer.

We cannot ignore the importance of secular ministry, not forgetting that Susanna was at that time a member of the Anglican Communion, a church structured with a hierarchy and ordered through precise roles. Everyone can make their gifts available to the growth of the whole. The strategy is essentially pragmatic, but also theologically well-founded. Which root mattered the most? Presumably the primacy goes to grace and service. The ready willingness to her neighbor prevented the natural critical sense of this modern woman from translating into negative judgment, disappointments, conflict, even towards her husband Samuel, who, more traditionalist and less practical than her, had not always managed to ensure good family care. Susanna always continued to respect him and to esteem him, as it is derived from this letter ${ }^{19}$ :

And did I not know that almighty Wisdom hath views and ends in fixing the bounds of our habitation which are out of our ken, I should think it a thousand pities that a man of his brightness and rare endowments of learning and useful knowledge in relation to the church of God should be confined to an obscure corner of the Country, where his talents are buried and he is determined to a way of life for which he is not so well qualified as I could wish.

The intellectual acumen did not shy away from theological disputes, as she admitted to being tempted by the antitrinitarian heresy of the Socinians ${ }^{20}$, but she remained faithful to the Trinitarian doctrine.

\footnotetext{
${ }^{18}$ Heitzenrater, Richard P. 1995. Wesley and the People Called Methodists.Nashville: Abingdon Press, 32.

${ }^{19}$ Oden, Patrick. 2013. "Let us not spend our time in triffling: Susanna Wesley, a mother to her sons". In Wesleyan Theological Journal 48(2), 112-125.

${ }^{20}$ Newton, 66.
} 


\section{International Journal of Social Science and Economic Research}

ISSN: $2455-8834$

Volume: 05, Issue: 06 "June 2020"

For her children, she was an authentic spiritual guide, equipped with specific catechetic tools. She recommended seeking God in all circumstances and through devotion. The communicative never lacked the life of faith with respect to God and between God and the creature, but also within God himself, given the distinction that Wesley makes in him, in the part in himself and beyond.

To narrate about the spiritual search typical of the climate of the Methodism of the origins, the spiritualist and awakening currents, to which so many were in need of a more authentic practice of faith, also remain the affirmations that trace the path of encounter between God and the creature, beginning from a willingness cultivated even through the serenity of the soul, free from harmful excesses ${ }^{21}$.

The mind of a Christian should always be composed, temperate, free from all extremes of mirth or sadness, and always disposed to hear the still small voice of God's Holy Spirit, which will direct him what and how to act in all the occurrences of life, if in all his ways he acknowledge him and depend on his assistance. I cannot now stay to speak of your particular duties. I hope I shall in a short time send you what I designed.

Direct contact with God cultivated through prayer represents the original and most tenacious root of Susanna's personality, already accustomed to theological reasoning thanks to the formation received in the family by her father ${ }^{22}$. This constant care also served as a stimulus for personal improvement in terms of service to the kingdom of God, to which she was addressed in this way $^{23}$ :

At last it came to my mind, though I were not a man, nor a minister of the gospel,...I might do somewhat more than I do...I might pray more for the people, and speak with more warmth to those with whom I have an opportunity of conversing. However, I resolved to begin with my children.

And motherhood became the privileged scope of her mission. She was convinced that christianly educating her children would mean changing the world for the better. And the day of home

21 Wallace, 50.

${ }^{22}$ Deen, Edith. 1959. Great Women of the Christian Faith. Chappaqua, New York: Christian Herald Books, 144.

${ }^{23}$ Miller Schmidt, Jean. 1999. Grace Sufficient: A History of Women in Early Methodism 1760-1939. Nashville, TN: Abingdon Press, 25.

Baker, Frank. 1981. "Susannah Wesley: Puritan, Parent, Pastor, Protagonist, Pattern". In Women in New Worlds: historical perspectives on the Wesleyan Tradition, edited by Hilah E. Thomas and Rosemary Skinner Keller. Nashville, TN: Abingdon Press. Vol. 2: 112-131. 


\section{International Journal of Social Science and Economic Research}

ISSN: $2455-8834$

Volume: 05, Issue: 06 "June 2020"

school with her children began and ended with prayer and a reading from the Bible ${ }^{24}$. And each child enjoyed a personal hour of dialogue with the mother according to a set timetable.

\section{PASTORAL MINISTRY}

As daughter and wife of a minister of the Church, Susanna was well aware of the difficulties associated with this commitment. When John expressed his intention to enter the sacred ordination, his father Samuel showed no enthusiasm at all and tried to dissuade him. The mother, on the contrary, welcomed with joy and warmth this purpose and wrote to him on this occasion $^{25}$ :

I was much pleased with your letter to your father about taking holy orders and liked the proposal. I approve your decision and think the sooner you are a deacon, the better.

From their university studies at Oxford, both John and George received precise hints about spiritual readings from their mother. These too marked their journey and enticed them to pastoral choice. When the two decided to leave for Georgia, the mother said ${ }^{26}$ :

If I had twenty sons, I would send them all.

When John returned to England, his mother was often by his side, while he preached for the countryside. She also encouraged him to let the laypersons preach.

However, it would be reductive to consider Susanna Wesley only as a reflection of the activity of the men in her family. She lived the pastoral ministry firsthand and with full consciousness, in line with the universal priesthood received by all the faithful through baptism. He experienced it first with an intense personal life of faith. Although she had to sail through the anguish of daily life, she managed the economy of a family burdened with the debts of her husband, who twice ended up in prison for this reason ${ }^{27}$. She had to overcome the hostilities of the enemies that her husband procured with his speech bluntly. And the revenges they put in place (they destroyed crops, killed cattle, in one circumstance they surrounded the house and started shooting, declaring that they wanted to kill Samuel, etc.) further undermined the family's finances. On the occasion of the two arson fires, in 1702 and 1709, they destroyed the house and put in serious

\footnotetext{
${ }^{24}$ Metaxas, 39.

${ }^{25}$ Deen, 146.

26 Hird, Ed and Janice. 2019. Susanna Wesley: mother on fire. Accessed October 12, 2019. http://lightmagazine.ca/2019/08/susanna-wesley-mother-on-fire/

${ }^{27}$ Ludwig, Charles. 1984. Susannah Wesley: Mother of John and Charles. Milford, Michigan: Mott Media, 118.
} 


\section{International Journal of Social Science and Economic Research}

ISSN: $2455-8834$

Volume: 05, Issue: 06 "June 2020"

danger the survival of the little ones of the house. Yet Susanna never lost her balance. She reserved at least one hour a day for personal prayer ${ }^{28}$.

She lived firsthand what she taught her children in the curriculum of study developed by herself, and she was also the first witness to them of the vital importance of prayer and contact with Scripture in everyday life, so that everyone in the house knew of don't have to disturb her at this hour dedicated to God. In her way of life the seed of the biblical method is inherent, the lifestyle from which the Methodists are born. And, in fact, Susanna is often remembered as the mother of Methodism. It is legitimate to overcome this position too, and to say that she did not live the pastoral ministry in reflection, but she assumed it on herself, even without public proclamations. In fact, the community, which gathered in her house on Sunday afternoon, recognized her charisma. John recognized it, remembering her in his life as a minister. She proclaimed it herself, refusing to stop the Bible-sharing service, which she organized around her kitchen table. The methodical rigor, that earned her sons, Oxford students and founders of the Holy Club ${ }^{29}$, the title of Methodists, seems to be a legacy given to them over time by their mother. And she had a fully-fledged ministry of leadership, the substance of which is present in her writings and prayers, all vibrant, like this one in which she even sketches a definition of religion ${ }^{30}$ :

Help me, Lord, to remember that religion is not to be confined to the Church, or closet, nor exercised only in prayer and meditation, but that everywhere I am in thy presence. So may my every word and action have a moral content. May all the happenings of my life prove useful to me. May all things instruct me and afford me an opportunity of exercising some virtue and daily learning and growing toward thy likeness. Amen

Susanna was actually a pastor. She was a pastor in her own family, which held together in the bond of faith, through the nourishment of the Spirit. She was a pastor by overcoming any mental restriction regarding the condition of the woman and she proved that by educating her daughters in the same way as their sons and not expecting from them any domestic help, before they were able to read. She was a reference point for her community, which gathered numerous and spontaneously around her, who satisfied their thirst for the Word of God.

\footnotetext{
${ }^{28}$ Metaxas, 41.

EpworthOldRectory. 2012. Susanna's influence. Accessed October 12, 2019. https://www.youtube.com/watch?v=VgaKx0BAUZ4.

${ }^{29}$ John and Charles Wesley organized the Holy Club at Christ Church College, Oxford, in 1729. The group's activities coincided with prayer, Bible reading, pious exercises, three or four times a week.

${ }^{30}$ Palma Ceia United Methodist Prayercast69. 2016. Susanna Wesley. Accessed October 12, 2019. https://www.youtube.com/watch?v=84WIsJptcv8.
} 
International Journal of Social Science and Economic Research

ISSN: 2455-8834

Volume: 05, Issue: 06 "June 2020"

In the early days of Methodism we find the inspiration of a special, simple and courageous woman, who let herself be guided by the Spirit and instilled a method of care and development, in gender equality, for faith, which her children gave name.

\section{REFERENCES}

Baker, Frank. 1981. "Susannah Wesley: Puritan, Parent, Pastor, Protagonist, Pattern”. In Women in New Worlds: historical perspectives on the Wesleyan Tradition, edited by Hilah E. Thomas and Rosemary Skinner Keller. Nashville, TN: Abingdon Press. Vol. 2.

British History Online. http://www.british-history.ac.uk/vch/middx/vol11/pp81-83.

Day, Alfred T. 2016. Susanna Wesley: mother of Methodism. http://www.umc.org/who-weare/susanna-wesley-mother-of-methodism.

Deen, Edith. 1959. Great Women of the Christian Faith. Chappaqua, New York: Christian Herald Books.

EpworthOldRectory. 2012. Susanna's influence. https://www.youtube.com/watch?v=VgaKx0BAUZ4.

Heitzenrater, Richard P. 1995. Wesley and the People Called Methodists. Nashville: Abingdon Press.

Hird, Ed and Janice. 2019. Susanna Wesley: mother on fire. http://lightmagazine.ca/2019/08/susanna-wesley-mother-on-fire/

Kirk, John. 1864. The Mother of the Wesleys: a biography. London: Henry James Tresidder.

Ludwig, Charles. 1984. Susannah Wesley: Mother of John and Charles. Milford, Michigan: Mott Media.

Metaxas, Eric. 2015. Seven Women and the Secret of their Greatness. Nashville Tennessee: Nelson Books.

Miller Schmidt, Jean. 1999. Grace Sufficient: A History of Women in Early Methodism 17601939. Nashville, TN: Abingdon Press.

Newton, John A. 1968. Susanna Wesley and the Puritan Tradition in Methodism. London: Epworth.

Oden, Patrick. 2013. "Let us not spend our time in triffling: Susanna Wesley, a mother to her sons”. In Wesleyan Theological Journal 48(2), 112-125. 
International Journal of Social Science and Economic Research

ISSN: 2455-8834

Volume: 05, Issue: 06 "June 2020"

Palma Ceia United Methodist Prayercast69. 2016. Susanna Wesley. https://www.youtube.com/watch?v=84WIsJptcv8.

Stepney. 1998. "Protestant Nonconformity to 1689". In A History of the County of Middlesex, edited by Thomas Baker, Vol. 11: 81-83. London: Victoria County History.

http://susannawesleyfoundation.org.

Tucker, Ruth A. 1988. First Ladies of the Parish: Historical Portraits of Pastors' Wives. Grand Rapids, MI: Ministry Resources Library, Zondervan Publishing House.

Wallace, Charles jr. 1984. "Susanna Wesley's spirituality: the freedom of a Christian woman". Methodist history, 22(3):158ss.

Wallace. 1989. "Some Stated Employment of Your Mind : Reading, Writing, and Religion in the Life of Susanna Wesley". In Church History 58(3), 354-366.

Wallace, Charles. 1997. Susanna Wesley: the complete writings. Oxford: Oxford University Press.

Wesley, John. 1829. The Works of the Rev. John Wesley, A.M.. edited by Thomas Jackson, John Mason. London: Longmans. Vol. I.

Wesley, Susanna. 1709. Devotional Journal. Bristol: Headingley MSS, Wesley College. Westburyon-Trym. 